\begin{tabular}{|l|l|l||}
\hline \multicolumn{2}{|c|}{ PublisherInfo } \\
\hline \hline PublisherName & $:$ & BioMed Central \\
\hline \hline PublisherLocation & $:$ & London \\
\hline \hline PublisherImprintName & $:$ & BioMed Central \\
\hline \hline
\end{tabular}

\title{
DCs and T-independent CSR
}

\begin{tabular}{|c|c|}
\hline \multicolumn{2}{|r|}{ ArticleInfo } \\
\hline ArticleID & 249 \\
\hline ArticleDOI & 10.1186/ar-2002-78451 \\
\hline ArticleCitationID & 78451 \\
\hline ArticleSequenceNumber & 2 \\
\hline ArticleCategory & Paper Report \\
\hline ArticleFirstPage & 1 \\
\hline ArticleLastPage & 3 \\
\hline ArticleHistory & $\begin{array}{ll}\text { RegistrationDate } & : 2002-10-11 \\
\text { Received } & : 2002-10-11 \\
\text { OnlineDate } & : 2002-11-19\end{array}$ \\
\hline ArticleCopyright & Biomed Central Ltd2002 \\
\hline ArticleGrants & \\
\hline ArticleContext & 130754411 \\
\hline
\end{tabular}




\title{
Keywords
}

\author{
APRIL, BLyS, CD40L (CD154), Class Switch Recombination, Dendritic Cells, Monocytes
}

\section{Context}

In response to antigen, mature B cells can generate diverse antibody effector function in the germinal centers of secondary lymphoid organs. This occurs through Ig class switching, which is critical to the generation of a protective immune response. Ig heavy chain class switching is mediated by class switch DNA recombination (CSR). CSR is thought to be highly dependent on the tumor necrosis factor (TNF) family member CD40L, whose expression is largely restricted to activated CD4 helper T cells. Previously, the existence of T cell independent CSR-inducing molecules other than CD40L has been implied. In this paper the authors show that antigen presenting cells (APCs), activated dendritic cells (DCs) and monocytes, may play a key role in CD40L-independent CSR through upregulation of the TNF family members, BLyS and APRIL, uncovering a novel link between innate and adaptive immunity.

\section{Significant findings}

CSR to "T-independent antigens" can occur in the absence of T cells (CD40L independent), but precisely how this happens is unclear. The mechanism of CD40L independent CSR has been investigated in this paper. The authors showed that DCs and monocytes (APCs) in the absence of T cells upregulated BLyS and APRIL upon stimulation with IFN $\alpha$ and IFN $\gamma$. Most importantly, APCs expressing BLyS and APRIL, or cell-independent BLyS and APRIL in the presence of IL-4, IL-10 or transforming growth factor (TGF)- $\beta$, induced CSR in B cells. Moreover, the authors were able to show that the antibodies generated by BlyS- and APRIL-driven CSR were functional. In fact, B cells matured into plasma cells and released antibodies upon stimulation of B cell receptor and by BLyS and APRIL, or in the presence of IFN $\alpha$ - or IFN $\gamma$-stimulated APCs and IL-15. Finally, in these experimental conditions induction of CSR was inhibited when BLyS- and APRIL-blocking reagents (anti-sBLyS, BCMA-Ig and TACI-Ig) were used, while no effect on CSR inhibition was noticed when CD40 stimulation was blocked with CD40-Ig. 


\section{Comments}

It is generally accepted that B cell CSR occurs in response to specific T cell help, and that such T cells have been previously activated by APCs. Litinskiy and colleagues have challenged this dogma. They have shown that APCs can directly stimulate B cell CSR through upregulation of BLyS and APRIL and in the presence of certain cytokines. These findings are remarkable because they substantially link innate immunity to the production of potential autoantibodies. They also give a possible explanation of the T cell-independent mechanism of isotype switching. One caveat of this work is that all the experiments were conducted in vitro. It is unclear how important such a mechanism is in vivo, or if the antigen specificity is sufficient to initiate the humoral immune response. Nevertheless, these findings simplify the requirements for CSR and, therefore, will invite a closer look at APC-B cell interactions.

\section{Methods}

Genomic DNA, Southern blotting and RT-PCR, FACS, ELISA and PBMC culture

\section{References}

1. Litinskiy MB, Nardelli B, Hilbert DM, He B, Schaffer A, Casali P, Cerutti A: DCs induce CD40-independent immunoglobulin class switching through BLyS and APRIL. Nat Immunol . 2002, 3(9): 822-829. 